\title{
KEPUTUSAN BERTRANSAKSI DAN KUALITAS PELAYANAN DITINJAU DARI PERSPEKTIF PROMOSI, TINGKAT SUKU BUNGA, DAN LOKASI PADA BPR DI WILAYAH SOLO RAYA
}

\section{TRANSACTION DECISIONS AND SERVICE QUALITY ASSESSED FROM PROMOTIONAL PERSPECTIVE, INTEREST RATE AND LOCATION OF BPR IN SOLO RAYA REGION}

\author{
Denny Mahendra \\ Sekolah Tinggi Ilmu Ekonomi AUB Surakarta \\ Jarot Santosa \\ Sekolah Tinggi Ilmu Ekonomi AUB Surakarta \\ Aris Tri Haryanto \\ Sekolah Tinggi Ilmu Ekonomi AUB Surakarta \\ Email : Arisharyanto26@yahoo.co.id
}

\begin{abstract}
ABSTRAK
Tujuan penelitian ini adalah untuk mengetahui hubungan tingkat suku bunga, promosi dan lokasi terhadap keputusan bertransaksi nasabah dengan kualitas pelayanan sebagai variabel intervening yang terjadi pada BPR di wilayah Solo Raya. Populasi dalam penelitian ini adalah nasabah yang bertransaksi di bulan Desember 2019 BPR di wilayah Solo Raya. Sampel dalam penelitian ini adalah sebesar $15 \%$ dari populasi yaitu sebesar 126 nasabah. Hasil penelitian menunjukkan bahwa Promosi berpengaruh negatif signifikan terhadap kualitas pelayanan, Tingkat suku bunga berpengaruh positif signifikan terhadap kualitas pelayanan, Lokasi berpengaruh positif signifikan terhadap kualitas pelayanan, Promosi berpengaruh positif signifikan terhadap keputusan bertransaksi, Suku bunga berpengaruh positif signifikan terhadap keputusan bertransaksi, Lokasi berpengaruh positif signifikan terhadap keputusan bertransaksi, Kualitas pelayanan berpengaruh positif signifikan terhadap keputusan bertransaksi Nasabah di BPR di wilayah Solo Raya.
\end{abstract}

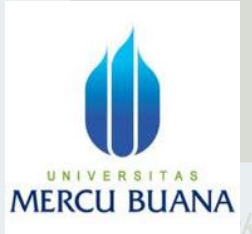

Jurnal Perilaku Dan Strategi Bisnis

Vol.8 No.2, 2020

Hal. $159-169$

Kata Kunci: promosi, suku bunga, lokasi dan kualitas pelayanan, Keputusan bertransaksi.

\section{ABSTRACT}

The purpose of this study was to determine the relationship between interest rates, promotions and location on customer transaction decisions with service quality as an intervening variable that occurs in BPRs in the Solo Raya area. The population in this study 
were customers who transacted in December 2019 BPRs in the Solo Raya area. The sample in this study amounted to $15 \%$ of the population, namely 126 customers. The results showed that promotion has a significant negative effect on service quality, interest rates have a significant positive effect on service quality, location has a significant positive effect on service quality, promotion has a significant positive effect on transaction decisions, interest rates have a significant positive effect on transaction decisions, location has a positive effect significant impact on transaction decisions. Service quality has a significant positive effect on Customer transaction decisions at BPRs in the Solo Raya area.

Keywords: promotions, interest rates, location and quality of service, transaction decisions.

\section{PENDAHULUAN}

Untuk memperoleh pangsa pasar para produsen harus memahami perilaku nasabah dalam hal memahami minat nasabah. Pemahaman akan perilaku nasabah ini memungkinkan dapat mempengaruhi minat nasabah sehingga mau membeli apa yang ditawarkan nasabah. Tujuan pemasaran sendiri menurut seorang pakar teori manajemen terbuka (Assauri, 2009:21), tujuan pemasaran adalah mengetahui dan memahami pelanggan dan selanjutnya mampu menjual dirinya sendiri. Idealnya, pemasaran harus memaksimalkan pelanggan yang siap membeli, yang dibutuhkan selanjutnya adalah menyediakan promosi atau jasa itu. Keputusan bertransaksi merupakan konsep yang penting khususnya pada kondisi pasar dengan tingkat pertumbuhan yang sangat rendah namun tingkat persaingannya sangat ketat, keberadaan nasabah yang bertransaksi pada suatu perusahaan sangat dibutuhkan agar perusahaan dapat bertahan (survive).

Penerapan strategi pemasaran yang tepat dapat mempengaruhi para calon nasabah untuk membuat suatu keputusan bertransaksi. Keputusan nasabah dalam mengambil keputusan bertransaksi dipengaruhi oleh akal pemikiran atas informasi pengetahuan yang didapatkan. Dimana faktor kualitas promosi, tingkat suku bunga dan lokasi merupakan beberapa faktor yang mempengaruhi pertimbangan nasabah dalam keputusan bertransaksi. Strategi mempertahankan nasabah dengan melakukan promosi yang gencar, tingkat suku bunga yang miring dan mencari lokasi perusahaan yang strategis, akan berdampak pada keputusan nasabah untuk membeli promosi yang ada. Promosi yang diberikan perusahaan berhubungan erat dengan keuntungan yang akan didapat oleh perusahaan, karena dengan promosi dan yang didapat nasabah akan mengikat nasabah sehingga perusahaan tersebut tertanam dalam benak nasabah, hal ini tentunya menguntungkan bagi pihak organisasi karena nasabah dapat melakukan promosi secara tidak langsung kepada teman, keluarga ataupun kepada orang lain untuk membeli produk dari perusahaan tersebut. Dalam penelitian ini variabel-variabel yang digunakan adalah promosi, tingkat suku bunga dan lokasi. Presepsi promosi sendiri merupakan hal yang diperhatikan oleh para nasabah dalam mengambil keputusan. Variabel promosi berkaitan dengan upaya mengembangkan "promosi" yang tepat bagi pasar target. Setiap menjalankan proses bisnis, baik promosi maupun jasa yang hendak dijual harus memiliki kualitas yang baik dan diharapkan sesuai dengan tingkat suku bunga yang diberikan.

Peningkatan kualitas promosi diharapkan dapat terus ditingkatkan bagi yang ingin membuka usaha baru, karena peningkatan kualitas promosi secara tidak langsung dapat mempengaruhi kepuasan nasabah, dan diharapkan nasabah dapat melakukan bertransaksi ulang atas promosi maupun jasa yang kita jual, sehingga secara otomatis dapat meningkatkan jumlah pendapatan perbulannya. Selain faktor kualitas promosi, tingkat suku bunga juga variabel penting dalam strategi pemasaran. Menurut Handoko (2015:56), pada setiap promosi atau jasa yang ditawarkan, bagian pemasaran berhak menetukan tingkat suku bunga pokoknya. 
Hasil penelitian yang relevan dilakukan oleh Budiarto (2011), Damar (2012), Margaretha (2014), Sumarmi, (2015), Ernawai, (2015), Siregar, (2016) menunjukkan bahwa promosi berpengaruh signifikan terhadap keputusan bertransaksi. Hasil penelitian yang dilakukan oleh Fahrudin, (2015) menunjukkan bahwa promosi berpengaruh tidak signifikan terhadap keputusan bertransaksi. Atas dasar fenomena, landasan teori dan kesenjangan hasi penelitian terdahulu (reseach gap) serta diasumsikan mendekati kondisi yang sebenarnya, maka akan diuji pengaruh promosi terhadap keputusan bertransaksi pada BPR di wilayah Solo Raya.

Salah satu strategi yang dapat dilakukan oleh para pengusaha dalam memberikan tingkat suku bunga kepada nasabah, ialah dengan memberikan tingkat suku bunga murah dibandingkan dengan pesaing lainnya, namun memberikan ciri khas yang berbeda dengan pengusaha lainnya, karena di Indonesia tingkat suku bunga merupakan masalah yang dianggap sensitif.

Faktor-faktor yang perlu dipertimbangkan dalam penerapan tingkat suku bunga tersebut antara lain biaya, keuntungan praktek persaingan, dan perubahan keinginan pasar. Rendah tingginya tingkat suku bunga yang diberikan kepada nasabah berpengaruh terhadap laku atau tidaknya suatu promosi dipasaran. Penetapan tingkat suku bunga oleh perusahaan sendiri harus disesuaikan oleh lingkungan dan perubahan yang terjadi dimana persaingan usaha semakin ketat seiringnya perkembangan waktu. Namun suatu tingkat suku bunga dapat juga menjadi suatu standar kualitas. Tidak jarang para nasabah rela berkorban memilih restoran yang tingkat suku bunganya relatif mahal demi mendapatkan promosi yang kualitas promosinya terjamin.

Hasil penelitian yang relevan dilakukan oleh Budiarto (2011), Damar (2012), menunjukkan bahwa tingkat suku bunga berpengaruh signifikan terhadap keputusan bertransaksi, sedangkan penelitian yang dilakukan oleh Sumarmi, (2015) menunjukkan bahwa tingkat suku bunga berpengaruh tidak signifikan terhadap keputusan bertransaksi. Atas dasar fenomena, landasan teori dan kesenjangan hasi penelitian terdahulu (reseach gap) serta diasumsikan mendekati kondisi yang sebenarnya, maka akan diuji pengaruh tingkat suku bunga terhadap keputusan bertransaksi pada BPR di wilayah Solo Raya. Faktor lokasi juga mempengaruhi sesorang dalam mengambil keputusan bertransaksi. Lokasi yang terletak dikeramaian atau mudah dijangkau oleh calon nasabah dapat dijadikan sebagai salah satu strategi yang dapat dilakukan oleh pemilik usaha. Seseorang maupun sekelompok orang cenderung memilih suatu obyek penjualan yang lokasinya tidak jauh dari lingkungan yang ramai. Komponen yang menyangkut lokasi menurut Tjiptono (2011:51) meliputi pemilihan lokasi yang strategis (mudah dijangkau), di daerah sekitar pusat perbelanjaan, dekat pemukiman penduduk, aman dan nyaman bagi pelanggan, adanya fasilitas yang mendukung, seperti adanya lahan parkir, serta faktor-faktor yang lainnya.

Hasil penelitian yang relevan dilakukan oleh Fahrudin, (2015), Sumarmi, (2015) menunjukkan bahwa lokasi berpengaruh signifikan terhadap keputusan bertransaksi, sedangkan penelitian yang dilakukan oleh Ernawai, (2015), Siregar, (2016) menunjukkan bahwa lokasi berpengaruh tidak signifikan terhadap keputusan bertransaksi. Atas dasar fenomena, landasan teori dan kesenjangan hasi penelitian terdahulu (reseach gap) serta diasumsikan mendekati kondisi yang sebenarnya, maka akan diuji pengaruh lokasi terhadap keputusan bertransaksi pada BPR di wilayah Solo Raya.

Bagi lembaga perbankan nasabah ibarat nafas yang sangat berpengaruh terhadap kelanjutan usaha suatu bank. Oleh karena itu, bank harus dapat mencari nasabah sebanyakbanyaknya agar dana yang terkumpul dari nasabah tersebut dapat diputar oleh bank yang nantinya disalurkan kembali kepada masyarakat yang membutuhkan bantuan bank. Menurut Tjiptono (2006:56) pengertian nasabah adalah setiap orang yang membeli dan 
menggunakan produk atau jasa perusahaan. Saladin (2014:43) nasabah adalah orang atau badan yang mempunyai rekening simpanan atau pinjaman pada bank.

Dalam kegiatan mengambil kredit nasabah banyak dipengaruhi oleh berbagai faktor baik itu faktor internal dan faktor eksternal. Kedua faktor tersebut sama-sama mempengaruhi keputusan nasabah dalam mengambil keputusan untuk melakukan pinjaman berupa kredit. Lebih lanjut Kotler (2006:78) menjelaskan bahwa yang mempengaruhi nasabah dalam mengambil suatu keputusan untuk mengambil kredit yaitu terdiri dari faktor tingkat suku bunga, jaminan, pelayanan, dan kebudayaan.

Tingkat suku bunga adalah tingkat suku bunga yang ditawarkan atas dana yang akan dikucurkan ke debitur. Tidak heran jika tingkat suku bunga menjadi variabel utama yang biasanya ditanyakan oleh calon debitur. Tingkat suku bunga yang murah tentu saja menjadi pilihan, di samping faktor lainnya. Namun calon debitur harus teliti karena tingkat suku bunga yang sama apabila sistem perhitungannya beda, maka kewajiban yang harus dibayarkan menjadi berbeda. Hal-hal yang terkait dengan tingkat suku bunga antara lain adalah: jangka waktu kredit, sistem angsuran, down payments, dan biaya-biaya yang harus ditanggung oleh debitur.

Faktor jaminan yang dimiliki calon debitur sangat penting bagi bank dan menjadi hal yang mempengaruhi layak tidaknya kredit. Ketika debitur sadar bahwa jaminan menjadi ketentuan dalam proses kredit, maka debitur dapat menilai apakah dirinya bankable atau belum. Sementara bagi debitur yang memiliki jaminan yang cukup bertingkat suku bunga maka persentase kredit yang dapat dicairkan atas jaminan akan mempengaruhi pengambilan kredit (loan to value). Di samping mempertimbangkan keamanan atas aset yang menjadi jaminan kredit.

Fenomena yang terjadi di BPR di wilayah Solo Raya adalah berorientasi pada pelayanan BPR di wilayah Solo Raya menjadi faktor yang banyak berpengaruh. Layanan yang dimaksud bisa mencakup kecepatan proses pencairan, kemudahan prosedur, kesediaan membantu dan memberikan bimbingan, teknologi perbankan yang memudahkan pembayaran, kedekatan lokasi dengan usaha, sampai dengan layanan pick up service. Pelayanan publik (public services) oleh BPR di wilayah Solo Raya dimaksudkan dalam mensejahterakan nasabah dari suatu pelayanan yang memadai, dan hal ini yang masih sering terabaikan. Nasabah yang memperoleh kepuasan atas produk yang dibelinya cenderung melakukan pembelian ulang produk yang sama (Dharmmestha, 2009). Teori di atas sesuai dengan fenomena atau keadaaan yang terjadi di BPR di wilayah Solo Raya bahwa nasabah yang ingin mengambil kredit sering kali yang ditanyakan pertama kali adalah tingkat suku bunga yang ditawarkan oleh BPR di wilayah Solo Raya, selain itu faktor pelayanan juga menjadi salah satu prioritas nasabah BPR di wilayah Solo Raya, bahwa dengan pelayanan yang baik nasabah akan tertarik atau percaya untuk mengambil kredit di BPR di wilayah Solo Raya. Hal ini tentunya tidak lepas dari jaminan yang menjadi dasar berapa banyak jumlah kredit yang akan dicairkan.

Berangkat dari fenomena dan pemikiran di atas, maka diperlukan penelitian berkenaan dengan pengaruh sistem penyampaian jasa tehadap tingkat suku bunga, promosi dan lokasi terhadap kualitas pelayanan dan keputusan bertransaksi nasabah, sehingga peneliti tertarik untuk melakukan penelitian mengenai "Keputusan Bertransaksi dan Kualitas Pelayanan Ditinjau dari Perspektif Promosi, Tingkat suku bunga, dan Lokasi Pada BPR di wilayah Solo Raya".

\section{METODE PENELITIAN}

Penelitian ini dilakukan dengan mengambil lokasi penelitian pada BPR di wilayah Solo Raya. Dalam penelitian ini yang menjadi objek penelitian ini adalah nasabah BPR di wilayah Solo Raya.Populasi dalam penelitian ini adalah nasabah yang bertransaksi di bulan 
Desember 2019 BPR di wilayah Solo Raya. Sampel dalam penelitian ini adalah sebesar 15\% dari populasi yaitu sebesar 126 nasabah.

\section{HASIL DAN PEMBAHASAN Analisis Jalur (Path Analysis)}

Hasil Analisis Jalur Persamaan 1

$\mathrm{Y} 1=-0,187 \mathrm{X} 1+0,457 \mathrm{X} 2+0,238 \mathrm{X} 3+\epsilon$

Dapat dijelaskan sebagai berikut:

1. Nilai $\beta 1$ sebesar $-0,187$ hal ini menunjukkan bahwa variabel promosi berpengaruh negatif terhadap kualitas pelayanan nasabah di BPR di wilayah Solo Raya, hal ini berarti apabila jika promosi ditingkatkan, maka kualitas pelayanan nasabah akan menurun.

2. Nilai $\beta 2$ sebesar 0,457 hal ini menunjukkan bahwa variabel suku bunga berpengaruh positif terhadap kualitas pelayanan nasabah di BPR di wilayah Solo Raya, hal ini berarti apabila suku bunga ditingkatkan, maka kualitas pelayanan nasabah di BPR di wilayah Solo Raya juga akan meningkat.

3. Nilai $\beta 3$ sebesar 0,238 hal ini menunjukkan bahwa variabel lokasi berpengaruh positif terhadap kualitas pelayanan nasabah di BPR di wilayah Solo Raya, hal ini berarti apabila lokasi ditingkatkan maka kualitas pelayanan nasabah di BPR di wilayah Solo Raya akan meningkat.

\section{Hasil Analisis Jalur Persamaan 2}

Persamaan kedua memasukkan variabel intervening kualitas pelayanan sebagai variabel independen.

$\mathrm{Y} 2=0,136 \mathrm{X} 1+0,454 \times 2+0,266 \mathrm{X3}+0,156 \mathrm{X} 4 .+\epsilon$

Dapat dijelaskan sebagai berikut:

1. Nilai $\beta 1$ sebesar 0,136 hal ini menunjukkan bahwa variabel promosi berpengaruh positif terhadap keputusan bertransaksi nasabah di BPR di wilayah Solo Raya, apabila promosi semakin baik maka keputusan bertransaksi Nasabah di BPR di wilayah Solo Raya akan meningkat.

2. Nilai $\beta 2$ sebesar 0,454 hal ini menunjukkan bahwa variabel suku bunga berpengaruh positif terhadap keputusan bertransaksi Nasabah di BPR di wilayah Solo Raya, hal ini berarti apabila suku bunga ditingkatkan maka keputusan bertransaksi Nasabah di BPR di wilayah Solo Raya akan meningkat.

3. Nilai $\beta 3$ sebesar 0,266 hal ini menunjukkan bahwa variabel lokasi berpengaruh positif terhadap keputusan bertransaksi nasabah di BPR di wilayah Solo Raya, hal ini berarti apabila lokasi ditingkatkan, maka keputusan bertransaksi nasabah di BPR di wilayah Solo Raya akan meningkat.

4. Nilai $\beta 4$ sebesar 0,156 hal ini menunjukkan bahwa variabel kualitas pelayanan berpengaruh positif terhadap keputusan bertransaksi nasabah di BPR di wilayah Solo Raya, hal ini berarti apabila kualitas pelayanan ditingkatkan maka keputusan bertransaksi nasabah di BPR di wilayah Solo Raya akan meningkat. 


\section{Uji t}

Uji t Persamaan Pertama

Tabel 1. Hasil Uji t analisis Jalur Persamaan 1

\begin{tabular}{|c|c|c|c|c|c|c|}
\hline \multicolumn{7}{|c|}{ Coefficients } \\
\hline \multirow{2}{*}{\multicolumn{2}{|c|}{ Model }} & \multicolumn{2}{|c|}{$\begin{array}{c}\text { Unstandardized } \\
\text { Coefficients }\end{array}$} & \multirow{2}{*}{$\begin{array}{c}\text { Standardized } \\
\text { Coefficients }\end{array}$} & \multirow[b]{2}{*}{$t$} & \multirow[b]{2}{*}{ Sig. } \\
\hline & & B & Std. Error & & & \\
\hline \multirow[t]{4}{*}{1} & (Constant) & 8,118 & 1,849 & & 4,390 &, 000 \\
\hline & Promosi &,- 162 & ,073 &,- 187 & $-2,218$ & ,028 \\
\hline & Tingkat Suku Bunga &, 531 & ,108 & ,457 & 4,903 &, 000 \\
\hline & Lokasi & ,219 &, 084 & ,238 & 2,609 &, 010 \\
\hline
\end{tabular}

a. Dependent Variable: Kualitas Pelayanan

Sumber : Data yang diolah, 2019

Dari hasil uji t persamaan pertama dapat dijelaskan sebagai berikut:

1. Promosi berpengaruh negatif signifikan terhadap kualitas pelayanan Nasabah di BPR di wilayah Solo Raya, hal ini dapat dilihat dari nilai signifikansi yaitu 0,028<0,05. Hal ini membuktikan bahwa hipotesis 1 yang berbunyi promosi berpengaruh signifikan terhadap kualitas pelayanan nasabah di BPR di wilayah Solo Raya terbukti.

2. Suku bunga berpengaruh positif signifikan terhadap Kualitas pelayanan Nasabah di BPR di wilayah Solo Raya, hal ini dapat dilihat dari nilai signifikansi yaitu 0,000<0,05. Hal ini membuktikan bahwa hipotesis 2 yang berbunyi suku bunga terhadap kualitas pelayanan nasabah di BPR di wilayah Solo Raya terbukti.

3. Lokasi berpengaruh positif signifikan terhadap kualitas pelayanan nasabah di BPR di wilayah Solo Raya, hal ini dapat dilihat dari nilai signifikansi yaitu 0,010<0,05. Hal ini membuktikan bahwa hipotesis 3 yang berbunyi lokasi terhadap kualitas pelayanan nasabah di BPR di wilayah Solo Raya terbukti.

\section{Uji t Persamaan Kedua}

Tabel 2. Hasil Uji t analisis Jalur Persamaan 2

\begin{tabular}{|c|c|c|c|c|c|c|}
\hline \multicolumn{7}{|c|}{ Coefficients } \\
\hline \multirow[b]{2}{*}{ Model } & & \multicolumn{2}{|c|}{$\begin{array}{l}\text { Unstandardized } \\
\text { Coefficients }\end{array}$} & \multirow{2}{*}{$\begin{array}{c}\text { Standardized } \\
\text { Coefficients } \\
\text { Beta } \\
\end{array}$} & \multirow[b]{2}{*}{$t$} & \multirow[b]{2}{*}{ Sig. } \\
\hline & & B & Std. Error & & & \\
\hline 1 & (Constant) & $-1,949$ & 1,492 & & $-1,306$ &, 194 \\
\hline & Promosi & ,121 & ,056 & 136 & 2,174 & ,032 \\
\hline & Tingkat Suku Bunga &, 546 & ,089 & ,454 & 6,139 &, 000 \\
\hline & Lokasi & 253 & ,065 & 266 & 3,911 & ,000 \\
\hline & Kualitas Pelayanan & ,161 & ,068 & 156 & 2,377 &, 019 \\
\hline
\end{tabular}

Sumber : Data yang diolah, 2019

Dari uji t persamaan kedua dapat dijelaskan sebagai berikut:

1. Promosi berpengaruh positif signifikan terhadap keputusan bertransaksi Nasabah di BPR di wilayah Solo Raya, hal ini dapat dilihat dari nilai signifikansi yaitu 0,032 <0,05. Hal ini membuktikan bahwa hipotesis 4 yang berbunyi promosi terhadap keputusan bertransaksi pada nasabah di BPR di wilayah Solo Raya terbukti.

2. Suku bunga berpengaruh signifikan terhadap keputusan bertransaksi Nasabah di BPR di wilayah Solo Raya, hal ini dapat dilihat dari nilai signifikansi yaitu $0,000<0,05$. Hal ini membuktikan bahwa hipotesis 5 yang berbunyi suku bunga terhadap keputusan bertransaksi nasabah di BPR di wilayah Solo Raya terbukti. 
3. Lokasi berpengaruh signifikan terhadap keputusan bertransaksi nasabah di BPR di wilayah Solo Raya, hal ini dapat dilihat dari nilai signifikansi yaitu $0,000<0,05$. Hal ini membuktikan bahwa hipotesis 6 yang berbunyi lokasi terhadap keputusan bertransaksi nasabah di BPR di wilayah Solo Raya terbukti.

4. Kualitas pelayanan berpengaruh signifikan terhadap keputusan bertransaksi nasabah di BPR di wilayah Solo Raya, hal ini dapat dilihat dari nilai signifikansi yaitu 0,019<0,05. Hal ini membuktikan bahwa hipotesis 7 yang berbunyi kualitas pelayanan terhadap keputusan bertransaksi nasabah di BPR di wilayah Solo Raya terbukti.

Hubungan antar variabel dapat digambarkan dengan bagan sebagai berikut:

Gambar 1. Pengaruh Langsung dan Tidak Langsung

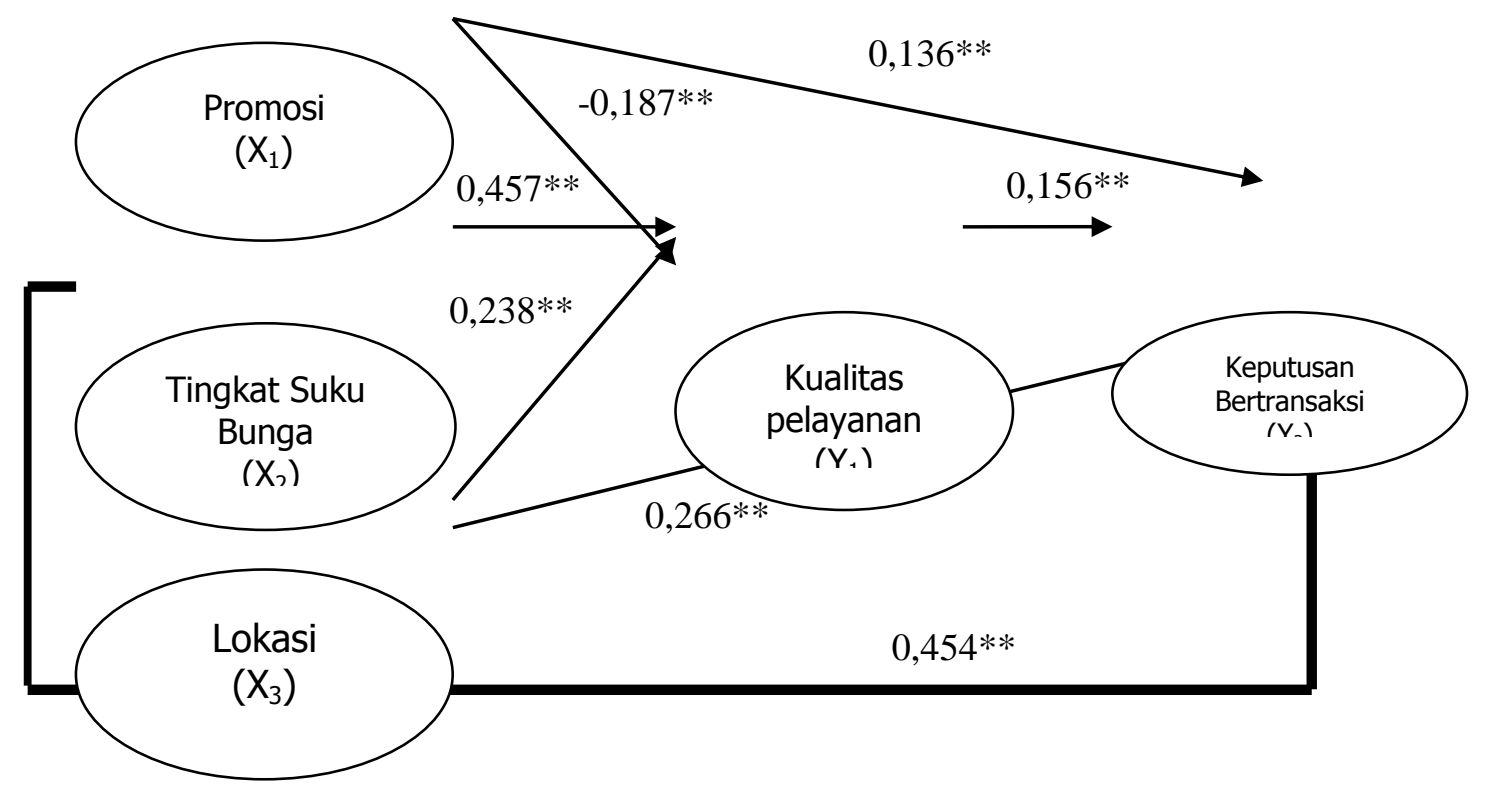

\section{PEMBAHASAN}

1. Pengaruh suku bunga terhadap keputusan bertransaksi melalui kualitas pelayanan.

Analisis jalur ini menunjukkan bahwa penggunaan variabel intervening kualitas pelayanan dalam rangka peningkatan keputusan bertransaksi, untuk variabel suku bunga adalah tidak efektif, karena pengaruh tidak langsung menghasilkan pengaruh yang lebih kecil dari pada pengaruh langsung. Hasil uji statistik menunjukkan suku bunga berpengaruh signifikan terhadap keputusan bertransaksi, sehingga suku bunga efektif secara langsung.

Hasil temuan ini sejalan dengan hasil penelitian yang relevan dilakukan oleh Wui (2010), Susasminto (2011) dan Ernawati (2015) yang menyatakan bahwa tingkat suku bunga berpengaruh positif terhadap keputusan bertransaksi.

Langkah-langkah untuk peningkatan suku bunga secara kongkrit, dapat ditingkatkan dengan melihat nilai indikator tertinggi uji validitas yaitu terletak pada item pertanyaan 4, 2 dan 5:
a. Menentukan tingkat suku bunga berdasarkan keadaan ekonomi nasabah.
b. Jangka waktu pengambilan kredit membuat suku bunga yang diberikan nasabah BPR di wilayah Solo Raya berbeda.
c. Keadaaan keuangan Negara menjadi salah satu gejolak dengan naik turunnya suatu suku bunga.


2. Pengaruh lokasi terhadap keputusan bertransaksi melalui kualitas pelayanan.

Analisis jalur ini menunjukkan bahwa penggunaan variabel intervening kualitas pelayanan dalam rangka peningkatan keputusan bertransaksi, untuk variabel lokasi adalah tidak efektif. Hal ini dapat dilihat dari hasil uji statistik bahwa lokasi signifikan terhadap keputusan bertransaksi, ehingga suku bunga efektif secara langsung.

Hasil temuan ini sejalan dengan hasil penelitian yang relevan dilakukan oleh Saptaningsih (2015) menyatakan dalam hasil penelitianya bahwa Lokasi berpengaruh tidak signifikan terhadap keputusan bertransaksi. Langkah-langkah untuk peningkatan lokasi secara kongkrit, dapat ditingkatkan dengan melihat nilai indikator tertinggi uji validitas yaitu terletak pada item pertanyaan 5, 4 dan 3:

a. BPR di wilayah Solo Raya jauh dari kepadatan arus lalu lintas.

b. BPR di wilayah Solo Raya jauh dari kemacetan.

c. Lingkungan yang mendukung untuk BPR di wilayah Solo Raya.

3. Pengaruh promosi terhadap keputusan bertransaksi melalui kualitas pelayanan.

Analisis jalur ini menunjukkan bahwa penggunaan variabel intervening kualitas pelayanan dalam rangka peningkatan keputusan bertransaksi, untuk variabel promosi adalah tidak efektif, karena pengaruh tidak langsung menghasilkan pengaruh yang lebih kecil dari pada pengaruh langsung. Hasil uji statistik menunjukkan promosi berpengaruh signifikan terhadap keputusan bertransaksi, sehingga promosi efektif secara langsung.

Hasil temuan ini sejalan dengan hasil penelitian yang relevan dilakukan oleh Damar (2010) menyatakan dalam hasil penelitianya bahwa promosi berpengaruh signifikan terhadap keputusan bertransaksi.

Langkah-langkah untuk peningkatan promosi secara kongkrit, dapat ditingkatkan dengan melihat nilai indikator tertinggi uji validitas yaitu terletak pada item pertanyaan 3,4 dan 2:

a. Adanya kenang-kenangan ketika selesai bertransaski membuat saya merasa dihargai waktu bertransaski di BPR di wilayah Solo Raya.

b. Adanya fasilitas yang lengkap membuat saya tertarik untuk bertransaski di BPR di wilayah Solo Raya.

c. Adanya pemberian jaminan pelayanan di BPR di wilayah Solo Raya membuat saya percaya untuk kembali.

\section{KESIMPULAN}

1. Hasil Uji Hipotesis

- Promosi berpengaruh negatif signifikan terhadap kualitas pelayanan nasabah di BPR di wilayah Solo Raya.

- Tingkat suku bunga berpengaruh positif signifikan terhadap kualitas pelayanan nasabah di BPR di wilayah Solo Raya.

- Lokasi berpengaruh positif signifikan terhadap kualitas pelayanan nasabah di BPR di wilayah Solo Raya.

- Promosi berpengaruh positif signifikan terhadap keputusan bertransaksi nasabah di BPR di wilayah Solo Raya.

- Suku bunga berpengaruh positif signifikan terhadap keputusan bertransaksi nasabah di BPR di wilayah Solo Raya.

- Lokasi berpengaruh positif signifikan terhadap keputusan bertransaksi nasabah di BPR di wilayah Solo Raya.

- Kualitas pelayanan berpengaruh positif signifikan terhadap keputusan bertransaksi Nasabah di BPR di wilayah Solo Raya. 
2. Hasil uji $F$ pada persamaan kedua diketahui besarnya nilai $F=54,122$ signifikansi $0,000<0,05$, sehingga dapat disimpulkan secara bersama-sama variabel promosi, suku bunga, lokasi dan kualitas pelayanan mempengaruhi Keputusan bertransaksi nasabah di BPR di wilayah Solo Raya.

3. Nilai R2 total sebesar 0,755 ini berarti bahwa keputusan bertransaksi nasabah di BPR di wilayah Solo Raya dijelaskan oleh variabel promosi, suku bunga, lokasi dan kualitas pelayanan sebesar $75,5 \%$ dan sisanya $24,5 \%$ dijelaskan variabel lain diluar model penelitian yaitu kualitas produk, harga dan jaminan pelayanan dengan alasan diprediksikan dapat mempengaruhi keputusan bertransaksi.

4. Hasil analisis jalur menunjukkan bahwa promosi, suku bunga dan lokasi efektif melalui jalur langsung. Hasil analisis jalur menunjukkan bahwa tingkat suku bunga mempunyai pengaruh yang paling dominan dalam meningkatkan keputusan bertransaksi di BPR di wilayah Solo Raya.

\section{DAFTAR PUSTAKA}

Adi, Krismanto, 2007, "Analisis Faktor-faktor yang mempengaruhi loyalitas pasien Klinik Assalam Klaten", Jurnal bisnis dan manajen Vol 4 No. 10 Pp. 123-236.

Anderson, E. and B. Weitz, 2003, "The Use of Pledges to Build and Sustain Commitment in Distribution Channel", Journal of Marketing research 29 (1), p.18-34.

Arikunto, Suharsini, 2011. Prosedur Penelitian Suatu Pendekatan Praktek Edisi ketiga.

Budi Gautama Siregar, 2016. Pengaruh Promosi dan Lokasi Usaha Terhadap Keputusan Peningkatan Jumlah Nasabah Produk Giro Wadiah di PT. Bank Sumut Cabang Syariah Padangsidimpuan Jurnal Penelitian IImu-ilmu Sosial dan Keislaman p-ISSN: 2442-7004 Vol. 02 No. 2 Desember 2016

Bolton, Ruth N and james H. Drew, 2001, " A Multi Stage Model of Customers Assessment of Service Quality and Value", Journal of Consumer Research, Januari, 1-9.

Bontis, Nick and Lorne D.Booker, 2007, "The mediating effect of organizational reputation on customer loyalty and service recommendation in rumah sakiting industry", Journal Management Decion, Vol.45, No.9 p.1426-1445.

Brown, Stephen W., 2001, "A Multi Stage Model of Customers Assesment of Service Quality and Value", Journal of Marketing, April, pp. 92-98

Cronin J.Joseph Jr and Steven A. Taylor (2002), "Measuring Service Quality : A reexamination and extension", Journal of Marketing Vol. 56 (July) p.55- 68

Carmel dan Tisher, 2004, Managing Human Resources: Productivity, Quality of Worklife and Profits, Singapore: Mc.Graw Hill International Editions.pp.68-75

Damar, 2012. Pengaruh promosi nasabah, lokasi dan tingkat suku bunga terhadap kualitas pelayanan dan keputusan bertransaksi Perusahaan Umum Daerah Karanganyar. Jurnal Ekonomi dan Bisnis Vol. 9 No.12

Dharmesta, Basu Swastha, 2009, "Loyalitas Nasabah : Sebuah kajian konseptual sebagai panduan bagi peneliti, "Jurnal Ekonomi dan Bisnis Indonesia, Vol.14, No.3

Djarwanto dan Subagyo, Pangestu, 2011: Statistik Induktif, Edisi: 4, Yogyakarta: BPFE 
Dwi Aryani, 2010. Pengaruh Kualitas Layanan terhadap Kepuasan Pelanggan dalam Membentuk Loyalitas Pelanggan, Bisnis \& Birokrasi, Jurnal IImu Administrasi dan Organisasi, Mei-Agus 2010, hlm. 114-126 ISSN 0854-3844 Volume 17, Nomor 21445

Fornell, 2014, "The American Customer Satisfaction Index : Nature, Purpose, and Findings". Journal of Marketing, 60 (10). (7 - 18).

Ghozali, Imam, 2014. Aplikasi Analisis Multivariate Dengan Program SPSS

Herbig, Paul, John Milewicz and Jim Golden, 2004. "A Model of Reputation Building and Destruction". Journal of Business Research. Vol.31, June 1994, No. 1 ; p.23-31.

Hirshman, 2012. Modul Analisa Data. Depok:FKM UI

Istijanto,2006, Riset Sumber Daya Manusia, Jakarta:PT. Gramedia Pustaka Utama

Juran, J.M., 2001, Quality Control Handbook, New York: Mc. Graw-Hill.

Kotler, Philip, 2013, Marketting Management, 11th ed. Upper Saddle River, New Jersey : Prentice Hall, Inc

Kotler, Philip, 2011, Manajemen Pemasaran, Edisi Millenium, Jakarta Prenhalindo

Kotler, Philip. 2008. Manajemen Pemasaran, Jilid 1, Jakarta, PT. Indeks Kelompok Gramedia.

Lamb, Chales W., Hair, Joseph F., and McDaniel, Carl. 2011. Pemasaran. Alih bahasa David Octavaria. Jakarta: Salemba Empat

Liu, Tsung-Chi and Li Wei Wu, 2007, "Customer retention and cross-buying in the rumah sakiting industry : An Integration of service attributes, satisfaction and trust" Journal of Financial Service Marketing, Vol.12 No.2 p.132-145.

Lupiyoadi, Rambat \& A. Hamdani. 2009. Manajemen Pemasaran Jasa, Edisi kedua, Jakarta, Salemba Empat

Margaretha M, 2014, "Study Mengenai Loyalitas Pasien Divisi Asuransi Kumpulan AJB Bumi Putera 1912 (Studi khusus di Jawa Tengah)", Jurnal Sains Pemasaran Indonesia, Vol III, No.3, Desember 2004. (289-308)

Muhammad Fajar Fahrudin, 2015. Pengaruh Promosi, Lokasi Dan Kualitas Pelayanan Terhadap Keputusan Nasabah Menabung Pada Bank Mandiri Di Surabaya. Jurnal Manajemen Dan Bisnis Stie Perbanas Surabaya Vol.1 No.2, 2015

Nachrowi, Djalal, 2006. Pendekatan Populer dan Praktis Ekonometrika Untuk Analisis Ekonomi dan keuangan. Jakarta: Lembaga penerbit Fakultas Ekonomi Universitas Indonesia.

Oliver, Richard L, 2007, "Satisfaction : A Behavioral Perspective on the Customer", McGrawHill, New York, NY

Parasuraman, A.,A.Zeithmal, V.,\& L.Berry, L.2005 "A conceptual Model of Service Quality and Its Implications for Future Research", Journal of Marketing, Vol.49 (fall). 
Peraturan Pemerintah Republik Indonesia No.25 tahun 1980 tentang perubahan atas Peraturan Pemerintah No. 26 tahun 1965 tentang Rumah sakit.

Prichard, mark P, 2010, "Analyzing the Commitment-Loyalty Link in Service Contexts", Journal of the Academy of Marketing Science 27 (3), p.333-348

Riduwan, 2005, Skala pengukuran Variabel-Variabel Penelitian, Cetakan Ketiga, Alfabeta, Bandung.

Sarwono, Jonathan. 2010. Analisis Jalur Untuk Bisnis dengan SPSS. Penerbit Andi Offset:Yogyakarta.

Saptaningsih Sumarmi, 2015. Analisis Pengaruh Promosi, Pelayanan, Lokasi, dan Tingkat Bunga Terhadap Minat Nasabah BKM Kecamatan Seyegan Kabupaten Sleman Yogyakarta. Publikasi Ilmiah Jurnal Riset dan Bisnis Universitas PGRI Yogyakarta. Vol.2 No.3 tahun 2015

Sekaran U, 2010. Research Methods For Business: A Skill Building Approach Singapore: John Willey dan Sonc, Inc

Selnes, Fred, 2013, "An Examination of the effect of Product Performance on Brand Reputation, Satisfaction and Loyalty", European Journal of Marketing, 27 (9). (19-35).

Staraus dan Seidel, 2006. Macroeconomic Factor and The Empirical Content of The Arbitrage Pricing Theory in The Japanese Stock Market"The Journal of Finance.

Setyo, Budiarto, 2011, "Pengaruh Kualitas Pelayanan terhadap Loyalitas Pasien dan Reputasi sebagai Variabel Intervening pada Apotek K-24 Jogjakarta"Jurnal Ekonomi dan Bisnis Vol. 5 No.11 Pp.45-56.

Solomon, Michael, 2006, Consumer Behavion, 3th edition, McGraw Hill.

Sugiyono, 2011. Metodologi Penelitian Bisnis, Cetakan Ketujuh, CV. Alpabeta, Bandung.

Susasminto, 2011, Pengaruh Kualitas Layanan Terhadap Kepuasan Dan Loyalitas Konsumen Circle K Di Surabaya. Jurnal bisnis dan manajen Vol 4 No. 10 Pp. 123-236.

Swastha, Basu. 2012. Azas-Azas Pemasaran, Yogyakarta, Liberty

Tatik Ernawai, 2015. Pengaruh Produk, Pelayanan, Promosi, Lokasi Dan Bagi Hasil Terhadap Keputusan Masyarakat Memilih Bank Syariah (Survey pada BTN Syariah Cabang Surakarta). Jurnal Manajemen Universitas Muhammadiyah Surakarta Vol.3 No.5 2015

Tjiptono, Fandi, 2012, Prinsip-prinsip Total Quality Service (TQS) , Andi Offset, Yogyakarta

Tronvoll, 2007, Journal Of Retailing. Vol 70, No.2, P.16" An Assesment Of The Relationship Between Service Quality And Customer Satisfaction In The Formation Of Consumers Purchase Intention",

Wei Wu, 2010. Service quality and cross-buying in the perusahaaning industry : An Integration of service attributes, satisfaction and trust. Journal of Financial Service Marketing, Vol.12 No.2 p.132-145. 